SCIREA Journal of Geosciences

http://www.scirea.org/journal/Geosciences

May 31, 2021

Volume 5, Issue 2, April 2021

\title{
Mysteries of the Epicenter and Magnitude of China's Mount Taishan Earthquake Solved
}

\author{
TIAN Hongshui ${ }^{{ }^{*}}$, YANG Chuan-cheng ${ }^{2}$, ZHANG Banghua ${ }^{3}$, ZHANG Shenhe ${ }^{1}$ \\ ${ }^{1}$ School of Civil Engineering, Shandong Jianzhu University, Jinan, China \\ ${ }^{2}$ Earthquake Engineering Research Center of Shandong Province, Jinan, China \\ ${ }^{3}$ College of Surveying \& Geo--informatics, Shandong Jianzhu University, Jinan, China \\ *Corresponding author. E-mail: tianhongshui@126.com
}

\begin{abstract}
:
The Mount Taishan earthquake, which named after Mount Taishan, occurred in 1831 BCE. It was the earliest historical earthquake recorded by historical writing-materials in China. However, seismic geologists have been unable to find any seismic-geological records or traces of the historical earthquake in the Taishan area and its surroundings. The epicenter and magnitude of this earthquake have remained unsolved mysteries. Through seismic and geological investigation and research, authors identified seismic records with soft-sediment deformation structures from the Holocene Heituhu Formation $\left(\mathrm{Q}_{4} \mathrm{H}\right)$ of the limnetic facies with soft soil layers in the Anqiu area (about $200 \mathrm{~km}$ from Mount Taishan) of the Yishu fault zone in the middle segment of the Tan-Lu fault zone, including seismic subsidence syncline, pinch-and-swell structure, as well as co-seismic micro-fault, and so on. Seismic subsidence
\end{abstract}


synclines and pinch-and-swell structures were outcomes of the obvious thixotropic deformation of silting soft soils triggered by a strong earthquake. The micro-faults were co-seismic micro-fractures that occurred at the same time as the former. In the seismic subsidence synclines, there are two-fold layers: the older black-gray layer of silty soft soil (average thickness $0.65 \mathrm{~m}$ ), and the newer yellow-gray sandy clay layer (average thickness $0.45 \mathrm{~m}$ ) in the fold core. The ${ }^{14} \mathrm{C}$ dating sample was taken from the top of the black-gray layer of silty soft soil, and the mean value of the ${ }^{14} \mathrm{C}$ dating results was converted into the year of $\mathrm{AD}$, which got the result is that the time of the formation of the soft soil was about 1887 BCE. However, the 1887 BCE was not the time of the earthquake, which should earliest occur the formation time of yellowish-gray sandy clay layer in the syncline core. According to the deposition rate of faulted lakes, it is estimated that the duration of sediment formation of the sand-clay layer with a thickness of $0.45 \mathrm{~m}$ was about 60 years. Accordingly, the earthquake recorded by the seismically deformed soil-layers occurred in $1827 \mathrm{BCE}$, which coincides with the occurrence time (1831 BCE) of the Mount Taishan earthquake as per historical records. Therefore, the epicenter of the Mount Taishan earthquake should lie in the Anqiu area. Based on the IX-degree seismic intensity corresponding to the obvious thixotropy of the saturated cohesive soil from simulated seismic tests, the magnitude of this historical earthquake is calculated to be Ms 7.0. Based on the seismic intensity attenuation model, the seismic intensity near Mount Taishan induced by the earthquake is calculated as VI degrees.

Keywords: Mount Taishan earthquake, epicenter, Anqiu, magnitude, soft-sediment deformation structure, thixotropy, seismic subsidence.

\section{Introduction}

According to The History of Natural Disasters in Shandong Province (Wei and Sun, 2000), the Mount Taishan earthquake, which occurred in 1831 BCE, was the earliest recorded historical earthquake in China. The Bamboo Annals also recorded that a strong earthquake 
suddenly occurred when the emperor named ' $\mathrm{Fa}$ ' of the Xia Dynasty was climbing Mount Taishan in 1831 BCE (Wei and Sun, 2000). However, the epicenter and the magnitude of this earthquake have always been mysteries. Chao et al. (1999) carried out a detailed seismic geological survey in the Tai'an area around Mount Taishan. They found that the latest active faults and seismic remains were formed from the Late Pleistocene to the Early Holocene. Therefore, there are no seismic geological records of an earthquake since the $19^{\text {th }}$ century BCE in the Tai' an area. Chao et al. (1999) concluded that the Mount Taishan earthquake was distant, the epicenter of which may be located in the nearby active fault zone (such as the Tanlu fault zone) with a magnitude of Ms8.5; or it was a 'local earthquake' (its magnitude $\leq$ Ms6.5) without surface rupture. So, some questions appeared "where was the specific epicenter of the earthquake?"; "What was the specific seismic geological record or the basis for measuring the magnitude?". Until this article is going to be published, there are no definite answers. Even Diao (2010) thought that the epicenter and magnitude of the Mount Taishan earthquake could not be determined, which was a puzzling problem. The authors have been engaged in the research of seismic events in the Yishu fault zone and its two sides (including Tai'an area) for many years and have discovered a considerable amount of seismic event strata with seismites. However, no seismic geological records of the 'Mount Taishan earthquake' were found in the Taian area (Tian et al., 2017). Nevertheless, many earthquake-induced soft-sediment deformation structures, such as seismic subsidence synclines, pinch-and-swell structures, seismic fissure filling, etc., were found in the Holocene Heituhu Formation in the Anqiu area within the Yishu fault zone, about $200 \mathrm{~km}$ from Mount Taishan. After carbon-14 dating of the organic soft soils in the Heituhu Formation that was deformed by earthquakes, combined with the analysis of the formation time of the relevant deformed soil layers, it was confirmed that the generation time of these seismic records was close to 1831 BCE. Therefore, the epicenter of the Mount Taishan earthquake is most likely to be in the Anqiu area, and the magnitude of the earthquake has been calculated to be Ms7.0; thus, lifting the two long-puzzled mysteries of the Mount Taishan earthquake. 


\section{Geological environment}

Mount Taishan is located in the north part of Tai'an City of Shandong Province in China; its main peak is $1,545 \mathrm{~m}$ above sea level, and it is known as 'the first of the five mountains of China'. The mountain lies in the west of the middle segment of the Tanlu fault zone in east China, about $200 \mathrm{~km}$ from the fault zone (Fig. 1). Mount Taishan is a fault-block mountain formed by the differential raising and lowering tectonic movement of the Cenozoic era and its formation age is about $30 \mathrm{Ma}$. (Zhang et al., 2000). Its tectonic unit named the Taishan Uplift is adjacent to the Jiyang Sag in the north (upper-left angle in Fig. 2). Jiyang sag has been subsiding since the Cenozoic and has deposited lacustrine-alluvial strata with a thickness of more than 4,000 meters (Song and Wang, 2003). Two long and narrow Cenozoic faulted basins (Taian-Laiwu Basin and Pingyi Basin) are developed near the southern side of Mount Taishan, which are filled with Cenozoic alluvial-shallow lacustrine facies and piedmont-diluvial facies with a thickness greater than 1,500 m. The part of Mount Taishan, which is $500 \mathrm{~m}$ above sea level, is composed of a Precambrian metamorphic complex. The foothill of Mount Taishan is mostly covered by Paleozoic strata (Song and Wang, 2003). From the Paleogene Changlu Formation and Zhujiagou Formation in the two faulted basins, various seismites were identified (Tian et al., 2017). Chao et al. (1999) found that the latest fault activities and seismic traces were formed in $1.42 \times 10^{4}$ a B.P. to $0.72 \times 104$ a B.P.

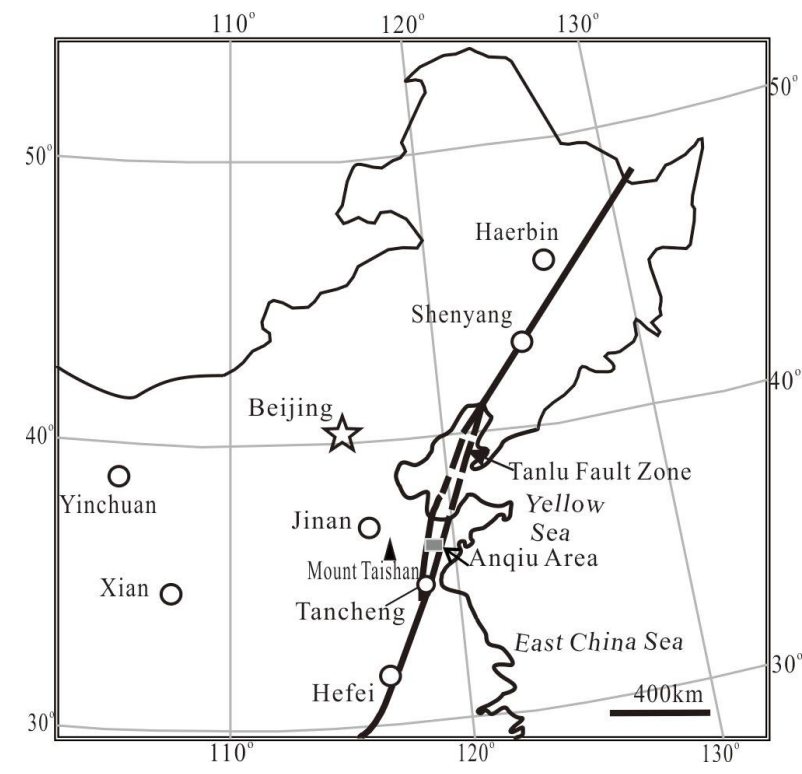

Fig. 1. Regional tectonic background of Mount Taishan and Anqiu area 


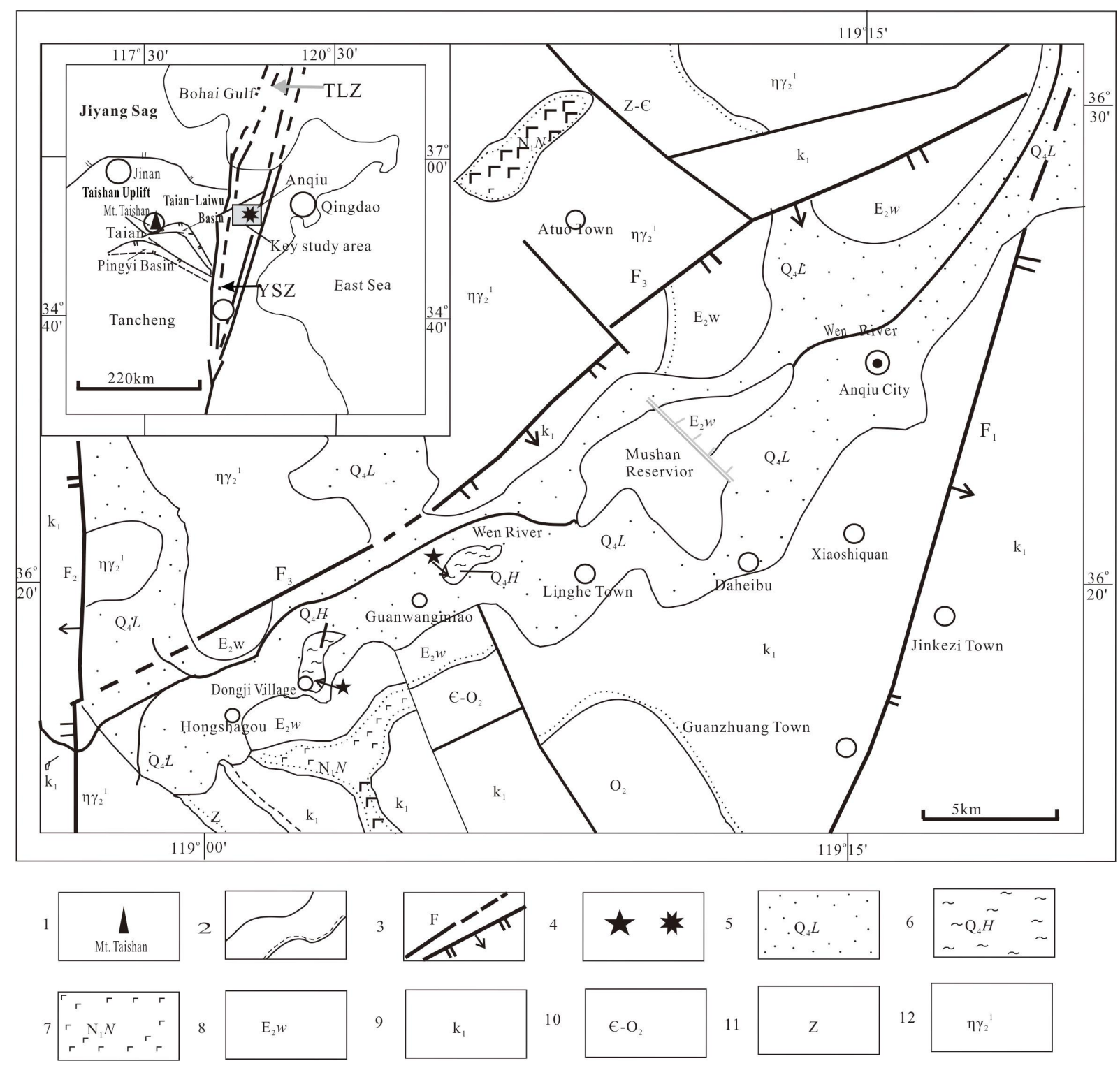

Fig. 2. Geological sketch of the Anqiu area in Shandong, China

1. Location of Mount Taishan; 2. Geological and unconformable boundaries; 3. Fault; 4. Key research site (left) and the possible epicenter (right); 5. Holocene Linyi Formation (alluvial); 6. Holocene Heituhu Formation (lacustrine-marsh soil); 7. Neogene Niushan Formation (basalt); 8. Paleogene Wutu Group; 9. Lower Cretaceous; 10. Cambrian-Middle Ordovician; 11. Sinian; 12. Mesoproterozoic adamellite; YSZ-Yishu fault zone; TLZ-Tanlu fault zone

The Yishu Fault Zone is $330 \mathrm{~km}$ long and $20-80 \mathrm{~km}$ wide. It runs through the center of Shandong Province in east China and belongs to the mid-segment of the Tanlu fault zone (Figs. $1 \&$ 2). It is a long active, strong seismic zone that developed abundant seismic records within and around the fault zone; and these seismic records are dominated by seismites with 
soft-sediment deformation structures (Qiao et al., 1994, 2001; Chao et al., 1995; Tian et al., 2003; Yuan et al., 2005; Yin and Yang, 2005; Yang et al., 2006; 2011; Zhou, 2011; Lü et al., 2011; He et al., 2011, 2012; Wang et al., 2013; Zhang et al., 2012; Tian et al, 2013, 2014, 2015a, 2016a, 2016b, 2017, 2018). Thereinto, seismogenic deformation structures of soil layers from the Holocene Heituhu Formation reflected the disaster of the seismic subsidence of soft soils formed during the $19^{\text {th }}$ century BCE in the Anqiu area, which provide evidence for the epicenter and the intensity of the Mount Taishan Earthquake. Soft soils are cohesive soils that contain organic matter formed in lakes, swamps, and deltas. They are often dark gray, with large pores, high water content, high compressibility, and low bearing capacity (Chen, 2003). According to the porosity ratio (e), soft soils are divided into mucky soil $(e>1-1.5)$ and silt $(e>1.5)$. Seismic subsidence of soft soil means: first, under the action of a strong earthquake, the subsidence phenomenon produced by the ground and the foundation of the structure above the soft soil layer is the most common form of earthquake damage; second, the thixotropic subsidence structure is formed by earthquake-triggered soft soil and belongs to one of the non-liquefied soft-sediment deformation structures (Yu and Shi,1989; Chen, 2003; Li et al., 2011; Tian et al., 2015, 2018; Su and Qiao, 2018).

The Anqiu-Xiazhuang Basin - a half-graben basin —is located in the central-southern part of the Anqiu region (Fig. 2). It is a Mesozoic-Cenozoic fault basin surrounded by two NNE-trending major trans-lithospheric faults $F_{1}$ and $F_{2}$, a NE-trending intra-crustal fault $\left(F_{3}\right)$, and the Gong-Danshan uplift to the south. All the above-mentioned faults underwent violent tectonic and seismic activity during the Cenozoic Era (Song and Wang, 2003).

On the periphery of the Anqiu-Xiazhuang Basin, Mesoproterozoic monzonitic granite and Sinian-Ordovician carbonate rocks are present. Volcanic clastic rocks of the Lower Cretaceous and alluvial-diluvial clastic sedimentary rocks interlayered with oil shale and mudstones of the Paleogene Wutu Group are distributed in the basin margin. The Holocene Heituhu Formation and the Linyi Formation are distributed 5-10 km riverside of the Wen River in the central-northern of the basin. The Heituhu Formation, from the bottom to the top, consists of blackish-gray silty clay (mucky soil) $(0.3-1.0 \mathrm{~m}$ thick) and yellowish-gray or yellow sandy clay $(0.2-0.8 \mathrm{~m})$, with a few outcrops in the northeast of Dongji Village and 
near Guanwangmiao Village, most of which have been reclaimed for tilling. The Heituhu Formation was formed in the lacustrine and swamp sedimentary environment, in the plain and inter-mountain basin setting, several thousands of years ago (Song and Wang, 2003). The Linyi Formation is the latest Holocene stratum. It is composed of alluvial sand and sandy conglomerate (2-8 m thick), which mostly overlies the hard plastic silty clay of the Dazhan Formation of the Upper Pleistocene. The Dazhan Formation is composed of silty clay (3-7 m thick), underlying the Holocene strata. The Dazhan Formation containing the silty clay is the water barrier of the lake bottom at that time. The top layer (0.8-1.2 thickness) was water-saturated, containing burrows of lake-dwelling animals. Therefore, this part of the silty clay was in a soft plastic state at that time.

\section{Seismic subsidence of soft soil and other earthquake-induced deformations of soil layers}

Outcrops of seismic subsidence synclines and earthquake-induced soil deformation structures are found in the soft soils of the Heituhu Formation and on the top of the Dazhan Formation in the east of the Dongji Village and near the Guanwangmiao Village (Fig. 2). Seismic subsidence of soft soil is a seismic disaster (ground pits caused by earthquakes). Because of the surface erosion and the tillage operations of the post-earthquake, any traces of these pits hardly are found on the surface today. However, the thixotropic subsidence synclines, co-seismic micro-faults, and other deformation structures still are clearly visible on the excavated or water-eroded scarp profiles (Figs $3 \& 4$ ). 


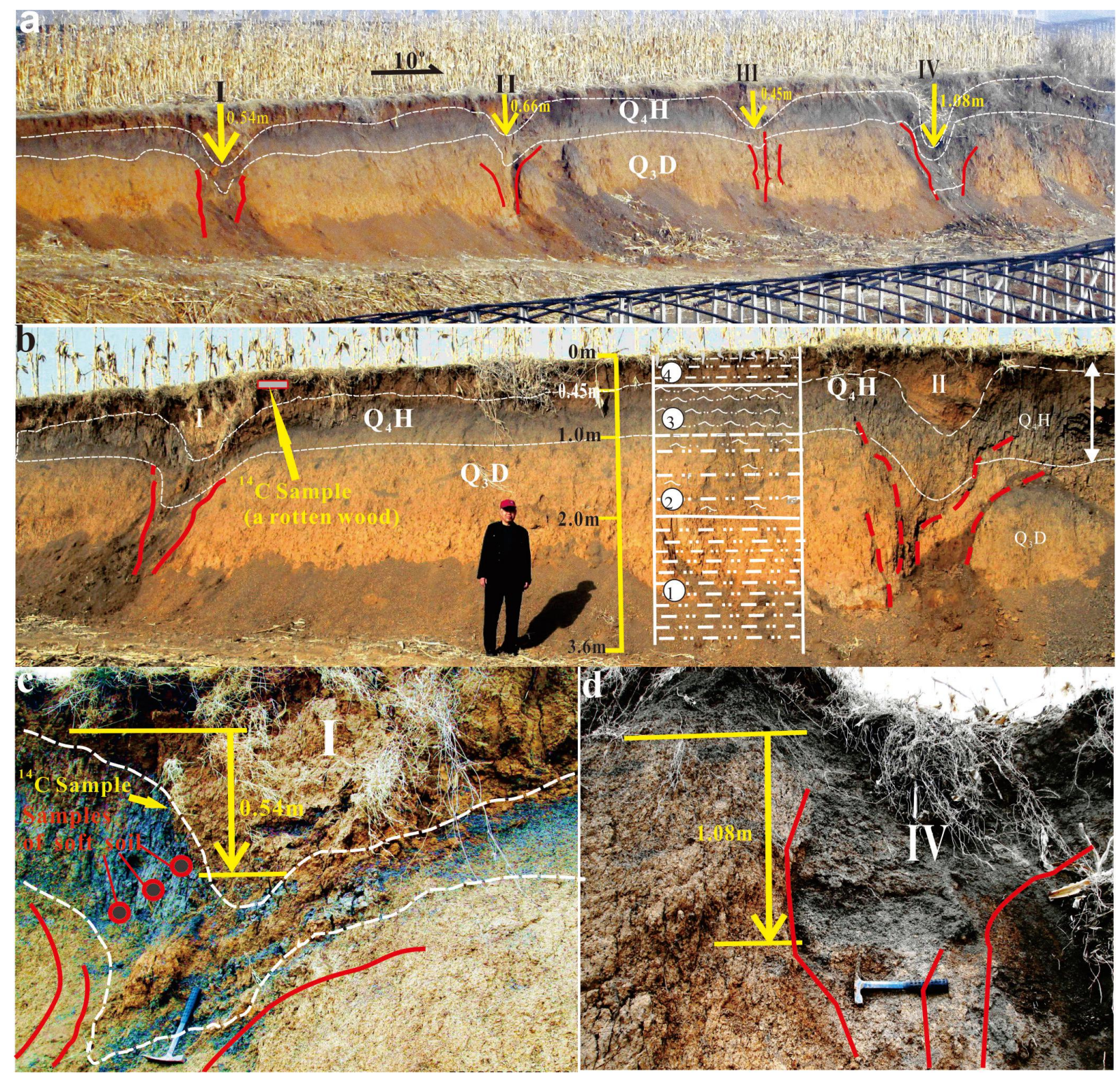

Fig. 3 Holocene earthquake-induced subsidence folds of soft soil and micro-faults on the east of the

\section{Dongji Village, Anqiu area}

a. Four narrow and deep subsidence synclines (I, II, III and IV) and several broad anticlines formed a set of trough-like folds in the manually excavated scarp. Some micro-faults (red lines) exist under these synclines, and subsidence depths of synclines I, II, III, and IV are $0.54 \mathrm{~m}, 0.66 \mathrm{~m}, 0.45 \mathrm{~m}$, and $1.08 \mathrm{~m}$ respectively; b. Strata of the scarp profile: Dazhan Formation $\left(\mathrm{Q}_{3} \mathrm{D}\right)$ \& Heituhu Formation $\left(\mathrm{Q}_{4} \mathrm{H}\right)$, (1)-silty clay (secondary loess), (2)-silty clay with animal burrows (filled with dark gray sandy clay), (3)-mucky soil (dark gray sandy clay with organic matter), (4)-sandy clay, the surface was transformed to tillage-humus soil; c. The yellow arrow points to the sampling location of the carbon-14 age, and the three red circles 
show the sampling positions for the soft soil; d. Near picture of the deepest syncline of seismic subsidence. All photos were taken facing west. The geologist in the middle of Photo $\mathrm{b}$ is $1.70 \mathrm{~m}$ tall.

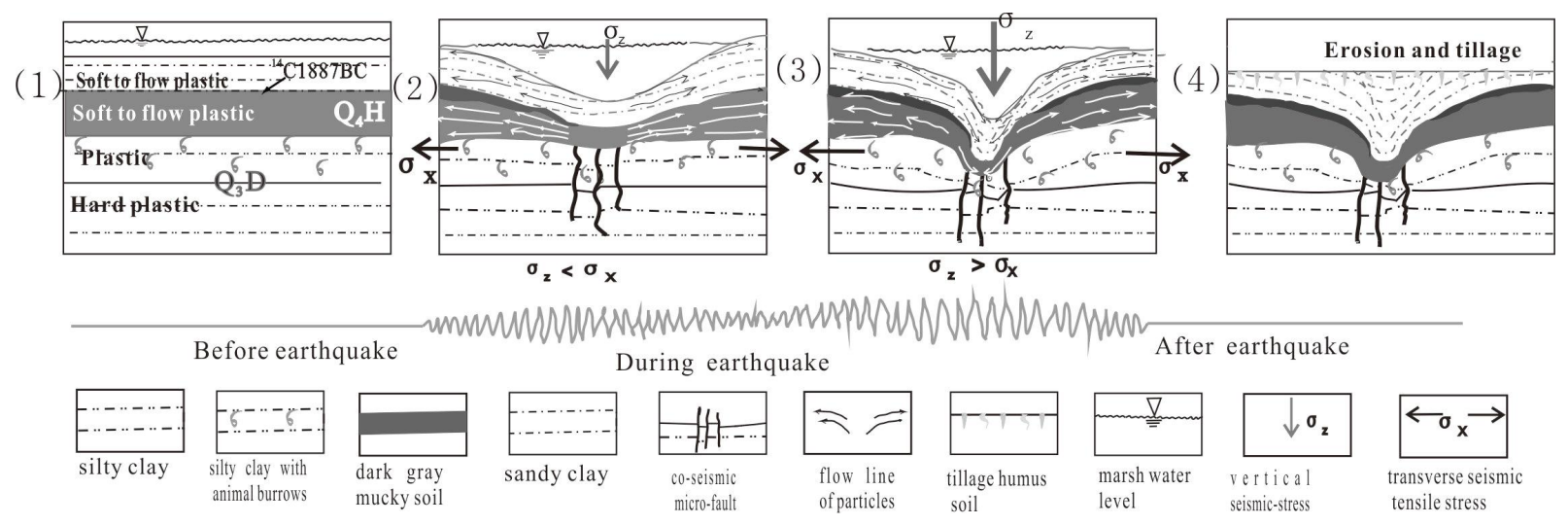

Fig. 4. Formation mechanism and process of the structure association of the subsidence syncline of soft soil and co-seismic micro faults.

\subsection{Thixotropy subsidence synclines of soft soil and co-seismic micro-faults}

\subsubsection{Description}

The combination of soft soil thixotropic subsidence synclines and micro-faults is clearly displayed on the east scarp profile of Dongji Village. As shown in Figure 3a, the scarp profile is $37 \mathrm{~m}$ long and $2.4-4.3 \mathrm{~m}$ tall. The overall occurrence of the soil layers is $10^{\circ} \angle 2^{\circ}-3^{\circ}$, and it is thicker in the north and thinner in the south. This reflects that the center of the limnetic zone occurred in the NNE direction of Dongji Village. As shown in Fig.3b, the scarp profile contains four layers of soil (from bottom to top): (1) silty clay (secondary loess), with an average thickness of $1.7 \mathrm{~m}$; (2) silty clay with animal burrows (filled with blackish-gray sandy clay), with an average thickness of $1.1 \mathrm{~m}$; (3) blackish-gray sandy clay with organic matter (mucky soil), with an average thickness of $0.65 \mathrm{~m}$; (4) sandy clay, where the top-soil was transformed to tillage humus soil, with an average thickness of $0.5 \mathrm{~m}$ (the initial thickness was greater than $0.5 \mathrm{~m}$ ). The layers (1) and (2) belong to the Dazhan Formation $\left(\mathrm{Q}_{3} \mathrm{D}\right)$; while the layers (3) and (4) belong to the Heituhu Formation $\left(\mathrm{Q}_{4} \mathrm{H}\right)$. The layer (3) is a typical soft-soil transformed by biological processes; while the layer (4) is a soft sandy-clay of the swamp facies that have not been altered by biological processes. The four narrow and 
deep subsidence synclines (Fig.3a: I, II, III, and IV) with the wide and gentle anticlines have formed a combination of trough-type folds. Subsidence depths of synclines I to IV are $0.54 \mathrm{~m}$, $0.66 \mathrm{~m}, 0.45 \mathrm{~m}$, and $1.08 \mathrm{~m}$, respectively, (Figs 3a I, II, III, and IV), with an average depth of $0.68 \mathrm{~m}$. The spatial form of subsidence syncline is bowl-shaped, with an interval of $6-8 \mathrm{~m}$ between them.

There are micro-faults with dipping angles of $55^{\circ}-70^{\circ}$ under the hinge zones of the synclines. The micro-faults, which are $0.5-1.8 \mathrm{~m}$ long, cut down the silty clay containing animal burrows at the bottom of the lake. The micro-fault planes are uneven, the upper part is slightly open, and the lower part has a partially straight shear-sliding surface. Thus, the micro-fault planes show mechanical features consistent with tension followed by shear-sliding. These micro-faults must be co-seismic micro-fractures (quasi-syn-sedimentary faults) formed at the same time as the subsidence syncline.

\subsubsection{Test of soft soil}

Three samples were collected from the lower, middle, and upper parts of the blackish-gray layer of the soft soil (Fig. 3-b(3), by the ring cutting method after removing the loose soil (Fig.3-c). The measures 'three basic physical property indexes' (average values) are as follows: a natural density $\rho=1.66 \mathrm{~g} / \mathrm{cm}^{3}$, a specific gravity of soil particle $d s=2.48$, and water content $w=11 \%$. The calculated natural void ratio $e=0.66$. This shows that the soft soil has become consolidated to a certain degree due to the effect of gravity. The measured soil compositions are — clay particles (mainly kaolinite and illite) $-52.5 \%$, fine sand $-19.8 \%$, silt - $16.3 \%$, and organic matter $-11.4 \%$.

The samples were crushed and soaked in water to obtain the original saturated limnetic facies soft soil. The measured saturated water content is $64.1 \%$, and the calculated void ratio $e=$ 1.28. Thus, this deposit is flow-plastic mucky soil. A liquid-plastic limit combined test was conducted using a photoelectric liquid-plastic limit device. The measured liquid limit of remodeled soft soil $w_{L}=47.6 \%$, the plastic limit $w_{P}=23.2 \%$, the plasticity index $\mathrm{I}_{\mathrm{P}}=14.4$, and the liquidity index $\mathrm{I}_{\mathrm{L}}=2.8$. As $\mathrm{I}_{\mathrm{L}}>1.0, \mathrm{I}_{\mathrm{P}}>10$, the original limnetic facies sedimentary soil was a flow-plastic cohesive soil (Chen, 2003). Accordingly, sediments can be divided 
into cohesive and non-cohesive sediments (Liu, 1980). The fluid-plastic cohesive soil is cohesive sediment. Due to strong earthquakes, saturated cohesive sediments undergo flow thixotropic deformations in various directions (Su and Qiao, 2018).

\subsubsection{Interpretation}

According to the Standard of Classification for Geological Disasters (DZ0238-2004), seismic subsidence of soft soil is a seismic disaster related to soft soil thixotropy. Saturated sand liquifies when subjected to strong earthquakes. Since the particles of saturated soft soil, soft clay, and colloidal sediments are small (diameter $<0.005 \mathrm{~mm}$ ), the surface of the particles has negative charge and there is an electrostatic attraction between them (Van der Vaals force). Given that the polar water molecules in the micropores are strongly adsorbed, saturated soft soil, soft clay, and colloidal sediments do not liquefy under strong earthquakes. However, due to strong earthquakes or external force, the texture of these sediments is destroyed and their viscosity and strength decrease; also, the plastic flow may occur. After an earthquake, the viscosity and strength gradually recover to a limited degree. The characteristic of saturated soft soil clay and colloidal sediments can change as soon as touch or trigger by an external force. This kind of "change at the touch of a trigger" is called thixotropy (Hou, 1998; Chen, 2003; Qiao et al., 2013). The thixotropic formation structures formed by earthquakes in saturated soft soil or clay include thixotropic subsidence folds, thixotropic bowls, thixotropic wedges, thixotropic columns, thixotropic veins, and muddy slump folds (Bowman et al., 2004; Montenat et al., 2007; Zhang et al., 2012; Basilone, 2017; Liang et al., 2018; Tian et al., 2018). The essence of seismic subsidence of soft soil is the residual deformation that cannot be recovered after the earthquake (Li et al., 2011). Studies by Yu and Shi (1989) have shown that with the occurrence of soft soil seismic subsidence and the increase in seismic subsidence value, the plastic flow deformation of saturated soft soil increases accordingly.

Based on the close symbiosis between the subsidence syncline formed by the soft soil seismic subsidence and the co-seismic micro-faults (Fig. 3), combined with the above-mentioned related research results, the formation mechanism and process are inferred, as shown in Fig.4: 
(1). Before the earthquake, the nearly horizontal layers of saturated sedimentary soil remained stable under constant self-weight stress.

(2). When a strong earthquake occurred, thixotropy of soil resulted due to the tensile seismic stress $\left(\sigma_{\mathrm{X}}\right)$ and vertical seismic stress $\left(\sigma_{\mathrm{Z}}\right)$, leading to plastic flow of the mass point of soft soil. Given that the seismic stress is non-uniform and tensive, co-seismic micro-faults were formed in the plastic to hard plastic soil layer $\left(\mathrm{Q}_{3} \mathrm{D}\right)$ under lakes and swamps, where the vertical seismic stress was greater than the tensile stress. At the same time, the saturated limnetic facies soil layer $\left(\mathrm{Q}_{4} \mathrm{H}\right)$ sank. While sinking, the flow-plastic soil layer $\left(\mathrm{Q}_{4} \mathrm{H}\right)$ flowed in the directions with less stress, resulting in an increased thickness of the soil layer on both sides. The late Pleistocene silty clay $\left(\mathrm{Q}_{3} \mathrm{D}\right)$ was buried deep, and only slight disturbance deformation occurred under seismic stress, except for the formation of co-seismic micro-faults.

(3). The vertical seismic stress increased, and the punching-shear-sliding of the micro-faults and the micro-faults developed deeper. The seismic subsidence developed deep and resulted in the information of a bowl-shaped pit (thixotropic bowl) on the ground. The plasticity of the soil particles was also slightly upward due to the two sides of the soil. The thickness of the soil layer on both sides became bigger and slightly upraised, and a gentle anticline was formed between two subsidence synclines.

(4). After the earthquake, the seismic stress disappeared. The viscosity, strength, as well as deformation of soft soil, were restored to some degree. However, the thixotropic subsidence folds and micro-faults remained as permanent deformations. Later on, as the crust rose and erosion took place, the bowl-shaped pit disappeared; and after a long period of tillage, a humus soil layer was formed on the ground surface.

Earthquake-induced seismic records are always accompanied by micro-faults, including seismo-genic syn-sedimentary micro-faults and co-seismic micro-faults (Seilacher,1969; Goffredo et al., 2002; Wheeler, 2002; Du et al.,2008; Li et al., 2008; Ma et al., 2009; Fu et al., 2008; Van Loon, 2009; Moretti and Van Loon, 2014; He et al., 2015; He and Qiao, 2015; Tian et al.,2016a). The micro-faults in Fig. 3 were formed slightly before the formation of the 
subsidence synclines, and these synclines were inclined and developed with the development of the micro faults toward the deep. The formation of micro-faults is an important factor in seismic-subsidence disasters.

\subsection{Pinch-and-swell structures and filled-in seismic fissures}

\subsubsection{Description}

The two types of soft-soil deformation structures are located on the newly-excavated scarps near Guanwangmiao Village (Fig. 2). Pinch-and-swell structures were observed at the bottom of a scarp about $4 \mathrm{~m}$ in height (Figs $5 \mathrm{a}$ and $\mathrm{b}$ ). They are boudinage structures of gray to grayish-black soft soil that contract and expand continuously. The soft soil becomes thinner at the pinch section and thicker at the swells. The maximum thickness is $1.4 \mathrm{~m}$ and the minimum thickness is $0.25 \mathrm{~m}$.

A seismic fissure was discovered in the light-gray lacustrine soil of the Heituhu Formation on another scarp (Fig.5c). The fissure is V-shaped in a vertical dimension, has straight sides, is $17 \mathrm{~cm}$ wide at its mouth, and $34 \mathrm{~cm}$ deep, and filled with dark gray soft soil. 

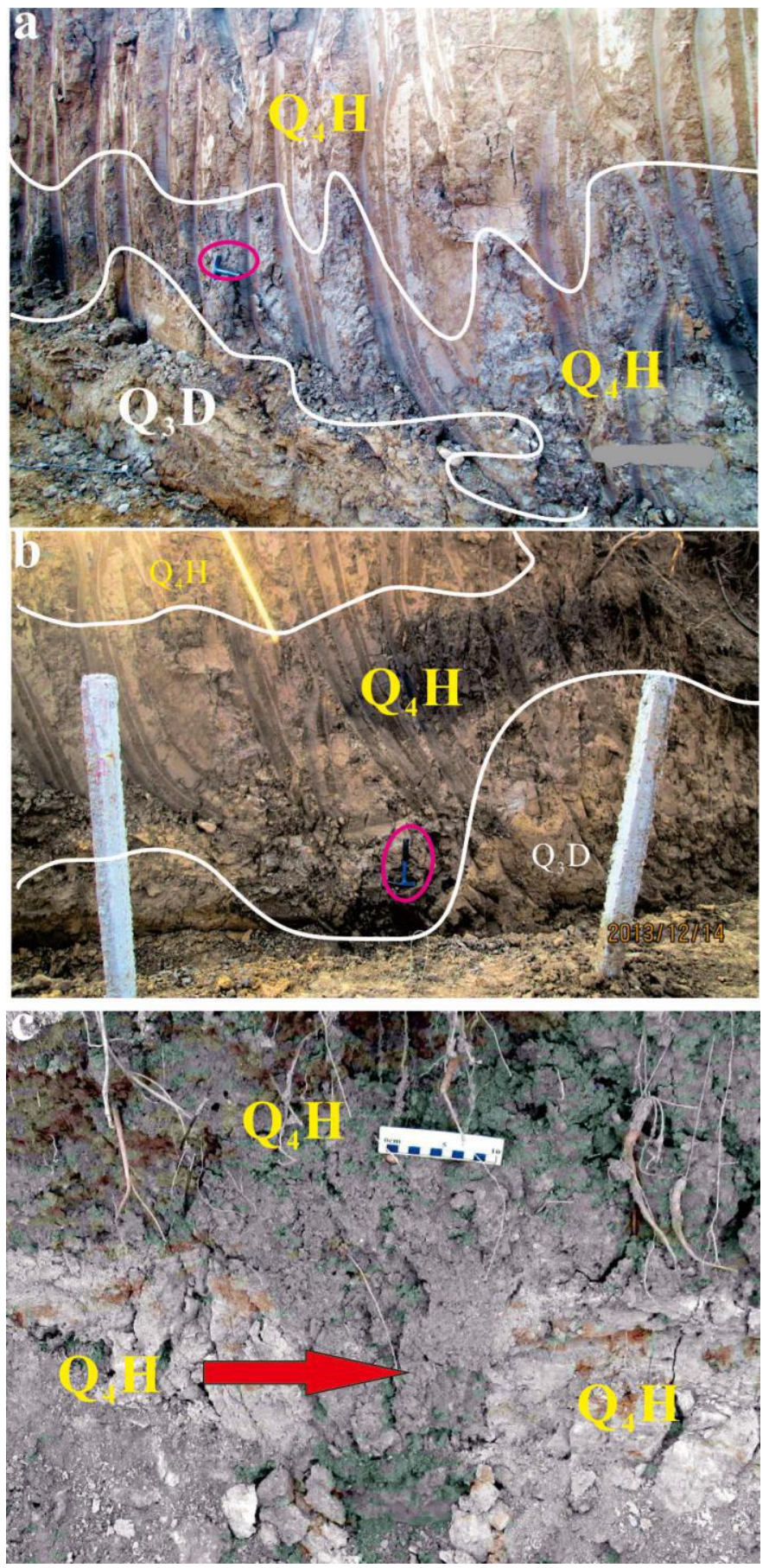

Fig. 5 Holocene earthquake-induced pinch-and-swell structure and seismic fissure near the

\section{Guanwangmiao in Anqiu area}

a and b.pinch-and-swell structures of dark soft soils;

c.seismic fissure; $\mathrm{Q}_{3} \mathrm{D}$ : Dazhan Formation; $\mathrm{Q}_{4} \mathrm{H}$ : Heituhu Formation. All photos were taken facing south.

The hammer's length is $0.3 \mathrm{~m}$. 


\subsubsection{Interpretation}

According to the experiment of $\mathrm{Wu}$ et al. (2005) and the principle of soft soil thixotropy (Zhang, 1989), the thixotropic course of saturated soft soils might undergo plastic flow under the effect of uneven vertical compressive stress and lateral tensile stress, which can lead to the formation of continuously extended uneven pinch-and-swell structures, (boudinage structures with pinch-and-swell characteristics). This soft-sediment deformation is evidence of seismic influence and occurred in different strata during different periods (Knaust, 2002; Martín-Chivelet et al., 2011; Van Loon and Su, 2013; Tian et al., 2015a, 2016a).

Filled-in seismic fissure structures are also common earthquake-induced deformation structures (Qiao et al., 1994; Qiao and Li, 2009; Tian et al., 2017). The filled-in seismic fissure structure in Fig.5c revealed that the edge of the lake-marsh basin was once exposed to the surface, and the pale-gray lacustrine soil was shaken and cracked, resulting in a seismic fissure with a ' $\mathrm{V}$ ' shape and more straight edges; after the earthquake, the lake-marsh deposition expanded and the seismic fissure was filled with the newer dark gray soft soil.

\section{Carbon-14 dating of soft soil, seismic trigger time and epicenter}

A soil sample, about $500 \mathrm{~g}$ from the top of the black-gray soft soil layer, was taken (Fig. 3c), and the Carbon-14 age was measured by the State Key Laboratory of Earthquake Dynamics of China in April 2014. Through testing and tree-ring correction, a carbon-14 dating result of $3901 \pm 33$ a B.P. was obtained. Therefore, the average carbon-14 age for 3901 a B.P., i.e. 1887 BCE, was taken as the formation time of the top layer of the blackish gray soft soil (Fig.4 (1)). This age value is earlier for 56 years than the 1831 BCE.

Because the yellow sandy clay on the black-gray soft soil is the core of the earthquake subsidence syncline (Fig .3 a), it shows that the earthquake event occurred after the formation of the yellow sandy clay. We collected 55 grams of the rotten wood from this layer of yellow sandy clay (20 cm below the ground) in 2020 and sent it to the carbon 14 laboratory of Nanjing University for dating. The result of the ${ }^{14} \mathrm{C}$ dating was $3866 \pm 23$ aB.P., the average 
3866 aB.P., i.e.1846 BCE. The age of the rotten wood was credible, only 15 years older than the 1831 BCE.

As the yellow sandy clay above the black-gray soft soil constitutes the core of the seismic subsidence syncline (Fig. 3a), this indicates that the relevant seismic event occurred after the formation of the yellow sandy clay layer, i.e., later than 1887 BCE. In faulted lakes, deposition rates of sediments are $2.4-12.5 \mathrm{~mm} / \mathrm{a}$, and the average rate is $7.5 \mathrm{~mm} / \mathrm{a}$ (Feng, 2013). The average deposition rate of $7.45 \mathrm{~mm} / \mathrm{a}$ was used to calculate the time of formation of the yellow sandy clay in this paper, and the calculated result was 60 a $(450 \mathrm{~mm} \div 7.45$ $\mathrm{mm} / \mathrm{a}=60.40 \mathrm{a} \approx 60$ a). As a result, the related seismic events occurred after $1827 \mathrm{BCE}$ (1887-60=1827BCE). Compared to $1831 \mathrm{BCE}$, the year $1821 \mathrm{BCE}$ had a time difference of only 1.60 per thousand $(1.60 \%)$. Therefore, it is inferred that seismogenic deformation structures of soft soils of the lake-marsh facies in the Anqiu area are the records of the Mount Taishan earthquake.

The quite macroscopic seismic records coincided with the seismogenic time of the Mount Taishan earthquake, such as subsidence structures, co-seismic micro-faults, and so on, were discovered in the Anqiu area (Figs. 3 and 5), which provide full evidences for determining the epicenter position of this historical earthquake. Therefore, the Anqiu area ought to be the epicenter of the Mount Taishan earthquake. About the no-existing of the epicenter of the Mount Taishan earthquake in the Tai'an area, there are two other additional reasons: the first one is that the previous special research showed that there was no seismic geological record of the historical earthquake in the active fault zones of the Tai' an area (Chao et al., 1999); and the second reason is that the details of the investigation of seismic deposition events that have done by the authors did not found any Holocene earthquake-induced sediment deformations in the mountain-front belt and inter-hill basins of the Tai'an area (Tian et al., 2017). 


\section{Discussions}

\subsection{Magnitude and intensity}

The seismic subsidence of soft soils is that of common earthquake disasters, such as the Tangshan earthquake in China of magnitude 7.6, which caused a large area of seismic subsidence of soft soils in the Tanggu area in 1976 CE (Liu, 1986; Li, 2011). The intensity map of the Tangshan earthquake with Ms7.6 showed that the Tanggu area was a VII-degree intensity area at that time; the average depth of uneven seismic subsidence was $8 \mathrm{~cm}$, and the maximum value of seismic subsidence was $18 \mathrm{~cm}$ (Zhang et al., 2017). However, so far, there has not been any research to determine the magnitude according to the scale and characteristics of the seismic subsidence of soft soils. From the dynamic triaxial tests of saturated soft soils (Zhang, 1989), thixotropy of the saturated soft soil begins to take place when the seismic intensity is $\geq$ VII-degree, and the bearing strength drops by $50 \%$ or more. The simulated seismic test by Tian et al. (2015b) proved that the minimum seismic intensity required for thixotropy of the saturated clay was VII-degree intensity. While the accelerated speed with IX-degree of seismic intensity was applied to the shaking table, the saturated clay layer in the test model had a marked thixotropic deformation leading to the formation of thixotropic wedges. The extent of seismic subsidence of the Holocene soft soil in the Anqiu area was quite deep; the maximum subsidence depth was $1.08 \mathrm{~m}$ (Fig. 3c), and the average subsidence depth was $0.68 \mathrm{~m}$, which indicated that an extent of the remarkable thixotropic deformation had been reached (Fig. 3). The seismic intensity had gone up to more than IX degrees at that time. According to the empirical relation formula between the magnitude Ms and the epicenter intensity $\mathrm{I}_{\mathrm{o}}, \mathrm{Ms}=0.66 \mathrm{I}_{\mathrm{o}}+0.98$ (Shi, 2007; Tian et al.,2013), taking $\mathrm{I}_{\mathrm{o}}=\mathrm{IX}$ degree, a conservative calculation has been carried out to obtain a magnitude $M s=6.96 \approx 7.0$.

\subsection{Intensity attenuation, isoline map, and human feeling}

From the above, it can be known that the epicenter of the Mount Taishan earthquake was in the Anqiu area, and the magnitude of the Mount Taishan earthquake was at least Ms7.0, with an epicenter intensity of IX degrees. So, what was the feeling of the emperor of the Xia Dynasty about the earthquake? To answer this question, it is necessary to analyze the change 
of earthquake intensity toward the west or the direction of Mount Taishan and to obtain the seismic intensity in Mount Taishan. According to the seismic intensity attenuation law and the model formula in North China during the $20^{\text {th }}$ century (Cui et al., 2010,); and taking $M=7$ and several epicenter distances ( $\mathrm{R}$ values), the seismic intensities of different places (including Mount Taishan) have been calculated, and the attenuation curves of seismic intensity have been drawn (Fig. 6). Since the long axis direction of the isoseismal map of seismic intensity in East China is dominated by NE-NNE direction and is consistent with the tectonic line (Shi and $\mathrm{Li}, 2001$ ), the long axis direction of the isoseismal map of Mount Taishan earthquake is NNE (Fig. 6b). By the projection of $\mathrm{R}=200 \mathrm{~km}$ in the intensity attenuation curve on the short axis in Fig. 6a, a VI-degree seismic intensity caused by the Mount Taishan earthquake has been obtained, which is the same as the calculation result of the short axis model $(I=1.7865+1.4523 \mathrm{M}-1.1155 \ln (\mathrm{R}+13)=1.7865+1.4523 \times 7-$ $1.1155 \ln (200+13)=5.972 \approx 6)$.

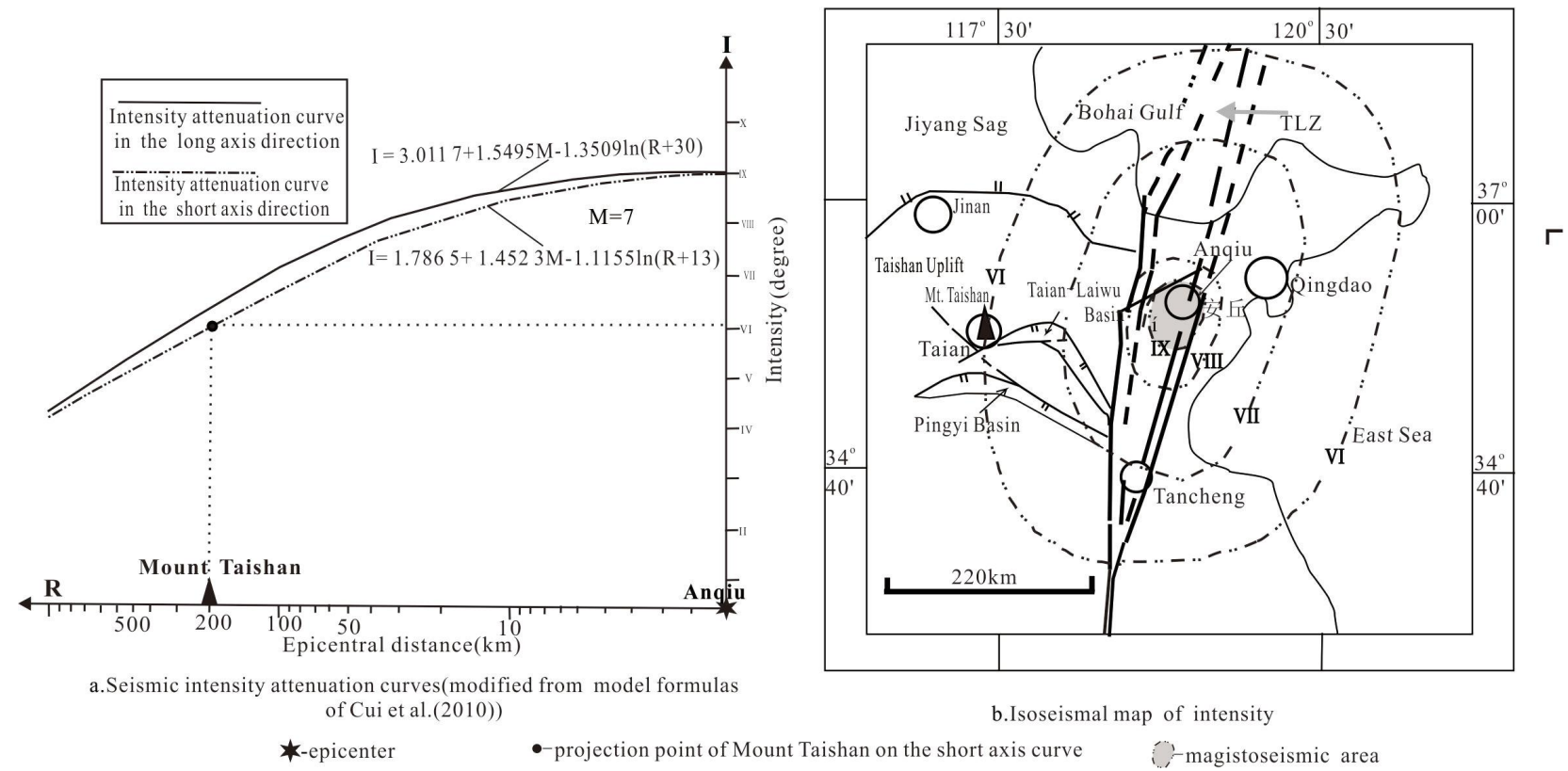

Fig.6 Seismic intensity attenuation curves (a) and reconstructed isoseismal map of intensity(b) of

\section{Mount Taishan earthquake}

The earthquake intensity scale of China (GB/T 17742-2008) shows that most people are unsteady, and a few of them flee outdoors in an earthquake intensity area of VI degrees. In 1831 BCE, the occurrence of the Mount Taishan earthquake resulted in a VI-degree earthquake intensity at Mount Taishan, that would have startled the emperor of the Xia 
Dynasty as he was climbing the mountain, and the people at the epicenter (Anqiu, with IX-degree seismic intensity area) would have been unable to stand and would have fallen over.

\section{Conclusion}

In $1831 \mathrm{BCE}$, when the emperor named 'Fa' of the Xia Dynasty was climbing Mount Taishan, he was startled by a strong earthquake. This historical earthquake was called the Mount Taishan earthquake and became part of the recorded history of China. However, it has been a mystery that has puzzled academia for a long time in identifying where the earthquake occurred and what was the seismic geological record of its epicenter and intensity. In this paper, the seismic geological records, isotopic age determination, geotechnical experiments of the soft soil, formation process of seismic subsidence, seismic intensity analysis, and seismic intensity attenuation, etc., provide detailed arguments for determining that the epicenter of the Mount Taishan earthquake was located in the Anqiu area, where its intensity was calculated. The relevant mystery answers have been uncovered.

The soft soil deformation structures in the Holocene soft soil layer of limnetic facies caused by the earthquake were records of the Mount Taishan earthquake in the $19^{\text {th }}$ century BCE, in the Anqiu area, within the Yishu fault zone. Since_previous studies did not discover any seismic residues related to the Mount Taishan earthquake, we have determined that the epicenter of this historical earthquake was not in the Tai'an area, but in fact, it was in the Anqiu area, which is consistent with the inference of Chao et al. (1999) that the epicenter of the Mount Taishan earthquake may be in a nearby active fault zone. Thus, it is inferred that the seismic subsidence folds of soft soils are significant thixotropic deformations of saturated cohesive soil; and the seismic intensity recorded is not less than IX-degree, and the magnitude is about 7.0. 


\section{Acknowledgements}

This work was supported by the National Natural Science Foundation of China ( NSFC-41272066), and the Program for Changjiang Scholars \& Innovative Research Team of the University of China (No.IRT-13075), and the Doctoral Research Fund of Shandong Jianzhu University (No. XNBS1708). We wish to thank Research-fellows Yin, Zheng \& Yang of the State Key Laboratory of Earthquake Dynamics of China Earthquake Administration for the soft soil ${ }^{14} \mathrm{C}$ dating.

\section{References}

[1] Basilone L, 2017. Seismogenic rotational slumps and translational glides in pelagic deep-water carbonates. Upper Tithonian-Berriasian of Southern Tethyan margin (W Sicily, Italy).Sedimentary Geology 356, 1-14.

[2] Bowman D, Korjenkov A and Porat N, 2004. Late-Pleistocene seismites from Lake Issyk-Kull, the Tien Shan range, Kyrghyzstan. Sedimentary Geology, 163: 211-228.

[3] Cui Xin, Miao Qing-jie and Wang Jin-ping, 2010.Model of seismic intensity attenuation for North China. North China Earthquake Sciences, 28(2):18-22 (in Chinese with English abstract)..

[4] Chao H T, Li J L., Cui Z W, Man H M and Du X S, 1995. Active faults in Tanlu fault zone and hazards produced by the 1668 Tancheng earthquake (M=8.5). Marine Geology \& Quaternary Geology, 15(3):69-79 (in Chinese with English abstract).

[5] Chao H T, Wang Z C, Li J L and Cui Z W, 1999. The latest activities of faults in the Taian region of Shandong Province and 'Taishan Mountain earthquake'. Seismology and Geology, 21(2): 105-114(in Chinese with English abstract).

[6] Chen, X. Z., 2003. Soil Mechanics and Geotechnical Engineering. Tsinghua University Press (Beijing),1-536 (in Chinese).

[7] Diao Ting, 2010. Interpretation of the Mount Taishan earthquake in the $7^{\text {th }}$ year of Emperor Fa's reign during the Xia Dynasty. Recent Development in World Seismology, 376(4):36-44 (in Chinese with English abstract). 
[8] Du Yuansheng, Xu Yajun and Yang Jianghai, 2008. Soft-sediment deformation structures related to earthquake from the Devonian of the eastern North Qilian Mts and its tectonic significance. Acta Geologica Sinica (English edition), 82(6): 1185-1193.

[9] Fu Xiaofang, Hou Liwei, Li Haibing, Wang Zongxiu and Zou Fuge, 2008. Coseismic deformation of the Ms 8.0 Wenchuan earthquake and its relationship with geological hazards. Acta Geologica Sinica, 82(2):1733-1746( in Chinese with English abstract).

[10] Goffredo M., Laura C, Marco B and Giacomo C, 2002. Indicators of paleoseismicity in the lower to middle Miocene Guadagnolo Formation, central Apennines, Italy. Geological Society of America Special Paper,359: 87-98.

[11] He Bizhu, Qiao Xiufu, Tian, Hongshui, Chen Shuqing and Zhang Youxia, 2011. Paleo-seismic event and the giant dinosaur fossil burial of Later Cretaceous, Zhucheng, Shandong province, China. Journal of Palaeogeography 13(6):615-626 (in Chinese with English abstract).

[12] He Bizhu, Qiao Xiufu, Tian, Hongshui, and Zhang Youxia , 2012. Paleoseismic events of Early Cretaceous and dinosaur migration in Zhucheng of Shandong province, China. Acta Geologica Sinica, 86(6): 1320-1330 (in Chinese with English abstract ).

[13] He Bizhu, Qiao Xiufu, Zhang Y. L., Tian, H.S.,Cai Z.H., and Zhang Y.X., 2015, Soft-sediment deformation structures in the Cretaceous Zhucheng depression, Shandong Province, East China; their character,deformation timing and tectonic implications. Journal of Asian Earth Sciences 110:101-122.

[14] He B.Z. and Qiao X.F.,2015. Advances and overview of the study on paleoearthquake events: areview of seismites. Acta Geologica Sinica,(English Edition), 89(5): $1702-1746$.

[15] Hou Wanguo, 1998. Application of Colloid Chemistry.Beijing:Science Press, 1-391 (in Chinese)..

[16] Knaust D. 2002. Pinch-and-swell structures at the Middle/Upper Muschelkalk boundary (Triassic): evidence of earthquake effects (seismites) in the Germanic Basin.International Journal of Earth Sciences, 90: 291-303. 
[17] Li, D., Chen, P. X., Lü, X.F. and Chen X.L., 2011. Research progress summarization for the earthquake subsidence of soft soil. Earthquake Resistant Engineering and Retrofitting, 33(2):130-135 (in Chinese with English abstract).

[18] Li Hai-bing, Fu Xiaofang,VAN der Woerd J V, Si Jialiang,Wang Zongxiu, Hou Liwei, Qiu Zhuli, Li Ning, 2008.Co-seisimic surface rupture and dextral-slip oblique thrusting of the MS 8.0 Wenchuan Earthquake Acta Geologica Sinica, 82(2):1623-1643( in Chinese with English abstract).

[19] Liang Lianji , Dai Fuchu, Jiang Hanchao and Zhong Ning, 2018. A preliminary study on the soft-sediment deformation structures in the late Quaternary lacustrine sediments at Tashkorgan, northeastern Pamir, China, Acta Geologica Sinica (English edition), 92(4): 1574-1591.

[20] Liu Baojun, 1980. Sedimentary petrology. Beijing: Geological Publishing House, 1-199 (in Chinese).

[21] Liu Huixian,1986.The Seismic Damages of the Great Tangshan Earthquake, Beijing:Seismological Press, 436-586(in Chinese).

[22] Lü Hongbo, Wang Jun and Zhang Haichun, 2011. Discovery of Late Mesozoic slump beds in Lingshan island, Shandong, and a pilot research on the regional tectonics. Acta Geologica Sinica 85(6): (in Chinese with English abstract).

[23] Martín-Chivelet, J., Palma,R. M., López-Gómez, J.and Kietzmann, D. A., 2011. Earthquake-induced soft-sediment deformation structures in Upper Jurassic open-marine microbialites (Neuquén Basin, Argentina). Sedimentary Geology 235: 210-221.

[24] Moretti, M, \& Van Loon, A.J., 2014. Restrictions to the application of 'diagnostic' criteria for recognizing ancient seismites. Journal of Palaeogeography 3(1): 13-24.

[25] Montenat, C., Barrier, P., Ott d'Estevou, P. and Hibsch, C., 2007. Seismites: an attempt at critical analysis and classification. Sedimentary Geology, 196 :5-30.

[26] Qiao, X.F., Song, T.R., Gao, L.Z., Peng, Y., Li, H.B., Gao, M.i, Song, B.and Zhang, Q.D.,1994. Seismic sequence in carbonate rocks by vibrational liquefaction. Acta Geologica Sinica (English edition), 68(1):16-29. 
[27] Qiao, X.F., Gao, L.Z., and Peng, Y., 2001. The Neoproterozoic in the paleo-Tancheng-Lujiang Fault Zone - catastrophe sequences biostratigraphy. Geological Publishing House (Beijing),1-122 (in Chinese).

[28] Qiao, X.F. and Li, H.B., 2009. Effect of earthquake and ancient earthquake on sediments. Journal of Palaeogeography,11(6): 593-610 (in Chinese with English abstract).

[29] Qiao, X. F., Li, H.B. and Qiu, Z. L., 2013. Seismite: ancient earthquake records in sedimentary rocks.[In:] Feng, Z.Z.( eds.) Chinese sedimentary rock. Petroleum Industry Press (Beijing), 507-15 (in Chinese).

[30] Seilacher, A., 1969. Fault-graded beds interpreted as seismites. Sedimentology 13: $155-159$.

[31] Shi, W., 2007. Engineering geology. Science Press (Beijing), 1-300 (in Chinese).

[32] Shi Zhen-liang and Li Yu-che, 2001. Seismic zonation in China. Engineering Science, 3(6):65-68(in Chinese with English abstract).

[33] Song, M.C. \& Wang, P.C., 2003. Regional geology of Shandong Province, Jinan: Map Press of Shandong Province, 1-970 (in Chinese).

[34] Su Dechen and Qiao Xiufu, 2018.Thixotropic deformation features of cohesive sediments triggered by palaeo earthquakes. Journal of Palaeogeography, 20(4):609-622.

[35] Tian Hongshui, Wan Zhongjie and Wang Hualin, 2003. Discovery and preliminary study on seismites of the Cambrian Mantou Formation in the central Shandong area. Geological Rev., 49(2): 123-131 (in Chinese with English abstract).

[36] Tian Hongshui, Zhang Zengqi, Zhang Banghua, Zhu Jiewang, Sang Zhongxi and Li Hongkui, 2013. Tectonic taphrogenesis and paleoseismic records from the Yishu Fault Zone in the initial stage of the Caledonian movement. Acta Geologica Sinica (English edition), 87(4): 936-947

[37] Tian Hongshui, Zhang Banghua, Zhang, Shenhe and Lü, Mingying, 2014.Neogene seismites and seismic volcanic rocks in the Linqu area, Shandong Province, E China.Geologos 20(2), 125-137.

[38] Tian Hongshui, Van Loon, A. J., Zhang Zengqi, Zhang, Shenhe and Zhang Banghua, 2015a. Neogene Paleoseismic vents and the Shanwang Biota's burial in the Linquarea, Shandong Province, China. Acta Geologica Sinica (English edition), 89(4): 1103-1119. 
[39] Tian Hongshui, Zhang Aishe, Zhang Shenhe, Zhang Banghua, Zhu Jiewang, Lü Mingying . 2015b. Simulation earthquake tests and liquefied deformations of the saturated lime-mud. Beijing: Seismological Press, 1-78 (in Chinese).

[40] Tian Hongshui, Van Loon, A. J., Wang Hualin, Zhang Shenhe and Zhu Jiewang, 2016a. Seismites in the Dasheng Group: new evidence of strong tectonic and earthquake activities of the Tanlu Fault Zone. Science China Earth Sciences, 59 (3): 601-618.

[41] Tian Hongshui, Zhang Shenheand Zhang Aishe, 2016b. Test investigation on liquefied deformation structure in saturated lime-mud composites triggered by strong earthquakes. Acta Geologica Sinica (English edition), 90(6): 2008-2021.

[42] Tian Hongshui, Zhu Jiewang, Wang Hualin, 2017.Spatio-temporal distribution and significance of seismic event horizons in the Yishu Fault Zone and its adjacent area. Journal of Palaeogeography, 19(3): 393-417( in Chinese with English abstract).

[43] Tian Hongshui, Wang Hualin, Zhu Jiewang and Zhang Shenhe, 2018. Earthquake-caused seismic volcanic rocks and thixotropic deformations of soft muddy sediments in EarlyCretaceous Shijiatunduan Member, Jiaozhou City. Seismology and Geology, 40(2):361-375.

[44] Van Loon, A.J., 2009. Soft-sediment deformation structures in siliciclastic sediments: an overview. Geologos 15, 3-55.

[45] Van Loon, A.J. and Su Dechen, 2013. Deformed stromatolites in marbles of the Mesoproterozoic Wumishan Formation as evidence for synsedimentary seismic activity. Journal of Palaeogeography 2, 390-401.

[46] Wei Guangxing and Sun Zhaomin, 2000. History of Natural Disasters in Shandong Province. Seismological Press (Beijing), 1- 256 (in Chinese).

[47] Wu Wujun, Zeng Zuoxun and Zhu Wenge, 2005. Research on rheology gauge of fish-head boudin. Advances in Earthscience 20, 925-932 (in Chinese with English abstract).

[48] Wheeler R.L., 2002. Distinguishing seismic from nonseismic soft-sediment structures: criteria from seismic-hazard analysis [In:] Ettensohn, F.R., Rast, N. \& Brett, C.E. (Eds): Ancient seismites. Geological Society of America Special Paper 359: 1-11. 
[49] Yang Jianping, Wang Yali, Zha Ming and Mu Xuemei, 2006. Discovery of the seismite surge wave deposits records of Paleogene in Huimin Depression, Shandong Province. Acta Geologica Sinica, 80(11): 1715-1720 (in Chinese with English abstract).

[50] Yin Xiulan. and Yang Tiannan, 2005. Seismites in the Laiyang Group in the Jiaozhou-Laiyang Basin, Shandong Province, and their tectonic implications. Geological Reviews 51, 502-507 (in Chinese with English abstract).

[51] Yuan Jing, 2004. The property and geological significance of seismites of Paleogene in Huimin sag, Shandong province. Acta Sedimentologica Sinica 22, 41-46 (in Chinese with English abstract).

[52] Yu Shousong and Shi Zhaoji, 1989. Experimental investigation of soil settlement due to earthquake. Chinese Journal of Geotechnical Engineering, 11, 35-46 (in Chinese with English abstract).

[53] Zhang Mingli, Jin Zhijun, Lü Pengju and Liu Guoli, 2000. Formation of Mount Taishan and Cenozoic tectonicism. Journal of Geomechanics, 6(2):23-29(in Chinese with English abstract).

[54] Zhang Huchen, 1989. Study on the earthquake thixotropy of mucky soil foundation.Chinese Journal of Geotechnical Engineering, 11, 78-85 (in Chinese with English abstract ).

[55] Zhang Jiuqi,Sun Rui,Yuan Xiaoming and Hou Longqing, 2017.The simplified formula for calculating the permanent strain potential of soft soil and parameter analysis.Earthquake Engineering and Engineering Dynamics, 37(5):103-108(in Chinese with English abstract ). 